\title{
1. Introduction to Recognition of Foreign Bank Resolution Actions
}

\subsection{NEW BANK RESOLUTION LAWS IN THE POST CRISIS ERA}

After the global financial crisis (GFC) of 2008, world leaders from G20 countries reached a consensus on the importance of 'strengthening transparency and accountability, enhancing sound regulation, promoting integrity in financial market and reinforcing international cooperation'. ${ }^{1}$ They called for the development of 'resolution tools and frameworks for the effective resolution of financial groups to help mitigate the disruption of financial institution failures and reduce moral hazard in future', inter alia, 'crisis management groups for the major cross-border firms' ${ }^{2}$ Much research has been done on causes of the financial crisis, the issue of 'too-big-to-fail', as well as on new mechanisms to address the problem of ailing financial institutions. ${ }^{3}$

Against this background, resolution emerged as the new response to the GFC. ${ }^{4}$ The intent is to prevent systemic failure and to avoid sacrificing tax-

1 G20, 'Declaration on Strengthening the Financial System - London Summit' (2 April 2009) 1.

2 G20, 'Leaders' Statement - The Pittsburgh Summit' (24-25 September 2009) 9.

3 See, e.g., Andrew Ross Sorkin, Too Big to Fail: The Inside Story of how Wall Street and Washington Fought to Save the Financial System - and Themselves (Penguin 2010); David Skeel, The New Financial Deal: Understanding the Dodd-Frank Act and Its (Unintended) Consequences (John Wiley \& Sons 2010); Todd A Gormley, Simon Johnson and Changyong Rhee, Ending 'Too Big To Fail' Government Promises vs. Investor Perceptions (National Bureau of Economic Research 2011); Viral V Acharya, The Social Value of the Financial Sector Too Big to Fail or Just Too Big? (Thorsten Beck and Douglas D Evanoff eds, World Scientific Publishing 2013); Andreas Dombret, Too Big to Fail III Should We Break Up the Banks? (Patrick S. Kenadjian ed, De Gruyter 2015).

4 See, e.g., Stijn Claessens and others, A Safer World Financial System: Improving the Resolution of Systemic Institutions (International Center for Monetary and Banking Studies 2010); Patrick S Kenadjian (ed), The Bank Recovery and Resolution Directive Europes Solution for 'Too Big To Fail'? (De Gruyter 2013); Matthias Haentjens and Bob Wessels (eds), Bank Recovery and Resolution A Conference Book (Eleven International Publishing 2014); Sven Schelo, Bank Recovery and Resolution (Kluwer 
payers' money to bail out banks. International organisations such as the Basel Committee on Banking Supervision (BCBS), the International Monetary Fund (IMF) and the Financial Stability Board (FSB) subsequently published several proposals on effective bank resolution and cross-border cooperation. In March 2010, the BCBS published the Report and Recommendations of the Cross-border Bank Resolution Group, proposing ten recommendations on 'legal and policy frameworks for cross-border resolutions and its follow-up work to identify the lessons learned from the financial crisis'. ${ }^{5}$ The IMF, on 11 June 2010, published the Resolution of Cross-Border Banks - A Proposed Framework for Enhanced Coordination, which highlighted the need for 'effective cooperation between authorities at the international level' as well as resolution frameworks at the national level. ${ }^{6}$

The FSB published a more detailed proposal the Key Attributes of Effective Resolution Regimes for Financial Institutions (Key Attributes or KAs) in $2011,{ }^{7}$ which was later updated in $2014 .^{8}$ The Key Attributes' objective is an effective resolution regime:

to make feasible the resolution of financial institutions without severe systemic disruption and without exposing taxpayers to loss, while protecting vital economic functions through mechanism which make it possible for shareholders and unsecured and uninsured creditors to absorb losses in a manner that respects the hierarchy of claims in liquidation. ${ }^{9}$

Law International 2015); Matthias Haentjens and Bob Wessels (eds), Research Handbook on Crisis Management in the Banking Sector (Edward Elgar 2015); Jens-Hinrich Binder and Dalvinder Singh (eds), Bank Resolution: The European Regime (OUP 2016); Michael Schillig, Resolution and Insolvency of Banks and Financial Institutions (OUP 2016); Simon Gleeson and Randall D Guynn, Bank Resolution and Crisis Management: Law and Practice (OUP 2016).

5 BCBS, 'Report and Recommendations of the Cross-border Bank Resolution Group' (March 2010).

6 IMF, 'Resolution of Cross-Border Banks - A Proposed Framework for Enhanced Coordination' (11 June 2010).

7 FSB 'Key Attributes of Effective Resolution Regimes for Financial Institutions' (October 2011).

8 FSB, 'Key Attributes of Effective Resolution Regimes for Financial Institutions' (15 October 2014). The 2014 version adopted additional guidance that elaborates on specific Key Attributes relating to information sharing for resolution purposes and sector-specific guidance that sets out how the Key Attributes should be applied for insurers, financial market infrastructure (FMIs) and the protection of client assets in resolution.

9 FSB Key Attributes, 3. 
These Key Attributes set out a general legal framework for an effective resolution law, which is recommended that national legislators incorporate into their national legal systems.

Accordingly, many of the FSB jurisdictions have amended their bank insolvency laws or promulgated new bank resolution laws. As of the end of 2019, some FSB jurisdictions, mostly the home jurisdictions of global systemically important bank (G-SIB), have implemented bank resolution regimes with comprehensive powers that are broadly in line with the Key Attributes. ${ }^{10}$ Of the 24 FSB jurisdictions, the European Union (EU) Member States (France, Germany, Italy, the Netherlands, Spain), the United Kingdom (UK), Hong Kong, Switzerland and the United States (US) have fully implemented resolution powers for banks (powers to transfer or sell assets and liabilities, powers to establish a temporary bridge institution, powers to write down and convert liabilities (bail-in), powers to impose temporary stay on early termination rights, resolution powers in relation to holding companies, recovery planning for systemic firms, resolution planning for systemic firms, and powers to require changes to firms' structure and operations to improve resolvability). ${ }^{11}$ Other jurisdictions have to some degree partially implemented resolution regime, and additional reforms are still ongoing. ${ }^{12}$

\subsection{CROSS-BORDER BANK RESOLUTION AND RECOGNITION OF FOREIGN BANK RESOLUTION ACTIONS}

Simply establishing domestic bank resolution regimes is not enough to achieve effective global bank resolution objectives and to avoid systemic failure across borders; a transnational bank resolution mechanism is needed, especially for resolving issues with large international banks. ${ }^{13}$ The FSB, among others, has been endeavouring to address the issue. The Key Attributes list KAs 7, 8 and 9 as a baseline for cross-border resolution. KA 7 is about the legal framework

10 FSB, 'FSB 2019 Resolution Report Eighth Report on the Implementation of Resolution Reforms "Mind the Gap"” (14 November 2019) 24-27.

11 Ibid.

12 Ibid.

13 Matthias Haentjens and Bob Wessels (eds), Research Handbook on Cross-border Bank Resolution (Edward Elgar 2019) xvii-xviii. See also Irit Mevorach, 'Beyond the Search for Certainty: Addressing the Cross-border Resolution Gap' (2015) 10 Brook J Corp Fin \& Com L 183; Vivien Chen, Andrew Godwin and Ian Ramsay, 'Cross-border Cooperation in Bank Resolution: A Framework for Asia' (2016) Singapore Journal of Legal Studies 1; Matthias Lehmann, 'Bail-In and Private International Law: How to Make Bank Resolution Measures Effective Across Borders' (2016) 66 International and Comparative Law Quarterly 107. 
conditions for cross-border cooperation, with 7.1 setting the general principle that ' $[\mathrm{t}]$ he statutory mandate of a resolution authority should empower and strongly encourage the authority wherever possible to act to achieve a cooperative solution with foreign resolution authorities'. ${ }^{14}$ KA 8 calls for the establishment of crisis management groups (CMGs) consisting of both home and key host authorities, which should be a platform for the authorities to cooperate and coordinate their actions in resolving cross-border institutions. ${ }^{15}$ KA 9 pursues institution-specific cross-border cooperation agreements, which set out detailed rules and procedures of both home and host authorities in the resolution process. ${ }^{16}$ In addition, the FSB published the Principles for Cross-border Effectiveness of Resolution Actions (FSB Principles) as a guideline, particularly focusing on the mechanism for giving effect to foreign resolution actions. ${ }^{17}$

In spite of these efforts made by international organisations, cross-border resolution is not adequately addressed by national laws or international laws, and 'limited mechanism for giving cross-border effect to resolution actions' is identified as one of the key challenges for the implementation of financial regulatory reforms. ${ }^{18} \mathrm{~A}$ central problem is the extraterritorial effect of a sovereign state's or its agency's actions, which, as a result of the exercise of sovereignty, can hardly have effects in another jurisdiction. Various solutions have been proposed to address this issue. In this regard, Haentjens, Wessels and Guo summarised four approaches. The first is private law solutions, which correspond to contractual measures of recognition, namely, incorporating provisions in financial contracts that recognise the effects of cross-border resolution actions. ${ }^{19}$ The second is cooperative solutions, which emphasise the cooperation of different national resolution authorities, such as information sharing,

\footnotetext{
$14 \quad$ KA 7.1.

15 KA 8.

16 KA 9.

17 FSB, 'Principles for Cross-border Effectiveness of Resolution Actions' (3 November 2015).

18 FSB, 'Implementation and Effects of the G20 Financial Regulatory Reforms 28 November 2018 4th Annual Report' (28 November 2018) 39. See also, e.g., FSB, 'Implementation and Effects of the G20 Financial Regulatory Reforms Report of the Financial Stability Board to G20 Leaders' (9 November 2015) 20-21; FSB, 'Implementation and Effects of the G20 Financial Regulatory Reforms 31 August 2016 2nd Annual Report' (31 August 2016) 17-18; FSB, 'Implementation and Effects of the G20 Financial Regulatory Reforms 3 July 2017 3rd Annual Report' (3 July 2017) 19; INSOL International, 'Bank Resolution: Key Issues and Local Perspectives' (December 2019) 69-75.

19 Matthias Haentjens, Bob Wessels and Shuai Guo, 'Conclusions' in Matthias Haentjens and Bob Wessels (eds), Research Handbook on Cross-Border Bank Resolution (Edward Elgar 2019) 401-403.
} 
the establishment of CMGs, entering into institution-specific cross-border cooperation agreements (CoAgs), and jointly formulating recovery and resolution plans (RRPs). ${ }^{20}$ The third approach concerns the recognition of foreign resolution measures, which mainly builds on the private international law instruments that can be unilaterally taken by host jurisdictions. ${ }^{21}$ And the fourth is global solutions, which aim to establish mandatory instruments at the global level, such as a supranational resolution authority. ${ }^{22}$ Ideally, as they suggested, these four solutions 'should be taken in parallel'. ${ }^{23}$

Many of the previous studies focus on cross-border cooperation between national (resolution) authorities. ${ }^{24}$ However, cooperation relies too much on political commitment instead of a predictable legal regime. ${ }^{25}$ Also, a global solution is difficult if not impossible to reach in the short term, due to high political negotiation costs. And private law solutions do not have binding effects on resolution authorities, which may lead to uncertainty issues.

Instead, this book focuses on the recognition mechanism, which relies primarily on a legal framework design. Although some authors have proposed to develop a new legal instrument for recognising foreign resolution actions, such as a model law, ${ }^{26}$ none of them has elaborated specific legal rules. This

20 Ibid., 403-404.

21 Ibid., 405-406.

22 Ibid., 406-407.

23 Ibid., 400.

24 See, e.g., Simon Gleeson, 'The Importance of Group Resolution' in Andreas Dombret and Patrick S. Kenadjian (eds), The Bank Recovery and Resolution Directive: Europe's Solution for 'Too Big To Fail'? (Walter de Gruyter 2013); Vincenzo Troiano, 'Cross-border Cooperation between Resolution Authorities in the BRRD' in Matthias Haentjens and Bob Wessels (eds), Research Handbook on Crisis Management in the Banking Sector (Edward Elgar Publishing 2015); Paul Davies, 'Resolution of Cross-border Groups' in Matthias Haentjens and Bob Wessels (eds), Research Handbook on Crisis Management in the Banking Sector (Edward Elgar 2015); Vivien Chen, Andrew Godwin and Ian Ramsay, 'Cross-border Cooperation in Bank Resolution: A Framework for Asia' (2016) Singapore Journal of Legal Studies 1; Costanza Russo, 'Third Country Cooperation Mechanism within the Bank Recovery and Resolution Directive: Will They Be Effective?' in Jens-Hinrich Binder and Dalvinder Singh (eds), Bank Resolution: The European Regime (OUP 2016); Jens-Hinrich Binder, 'Cross-border Coordination of Bank Resolution in the EU: All Problems Resolved?' in Matthias Haentjens and Bob Wessels (eds), Research Handbook on Cross-border Bank Resolution (Edward Elgar 2019).

25 Shuai Guo, 'Cross-border Resolution of Financial Institutions: Perspectives from International Insolvency Law' (2018) 27 Norton Journal of Bankruptcy Law and Practice 481, 500-502.

26 See, e.g., Jonathan M Edwards, 'A Model Law Framework for the Resolution of G-SIFIs' (2012) 7 Capital Markets Law Journal 122; Mevorach (n 13); Matthias Haentjens, Lynette Janssen and Bob Wessels, New Bank Insolvency Law for China 
book, therefore, intends to closely study the mechanism that gives effect to foreign resolution actions, pays special attention to the question of what the legal framework for recognition of foreign bank resolution actions should be, and proposes detailed legal principles.

Recognition of foreign resolution actions is emphasised in FSB KA 7.5, which reads:

Jurisdictions should provide for transparent and expedited processes to give effect to foreign resolution measures, either by way of a mutual recognition process or by taking measures under the domestic resolution regime that support and are consistent with the resolution measures taken by the foreign home resolution authority. Such recognition or support measures would enable a foreign home resolution authority to gain rapid control over the firm (branch or shares in a subsidiary) or its assets that are located in the host jurisdiction, as appropriated, in cases where the firm is being resolved under the law of the foreign home jurisdiction. Recognition or support of foreign measures should be provisional on the equitable treatment of creditors in the foreign resolution proceeding. ${ }^{27}$

This book thus understands 'recognition' in a broad sense and examines both mutual recognition process and supportive measures, collectively characterised by the FSB as 'statutory approaches' ${ }^{28}$ Mutual recognition means recognising the effects of foreign resolution actions, while taking supportive measures is on the condition that a foreign resolution action is recognised as effective and requires host jurisdictions to implement home resolution actions. This distinction resembles the regime of recognition and enforcement of foreign judgments: any judgment that needs to be enforced needs to be recognised, yet not every judgment needs to be recognised needs to be enforced.$^{29}$ Recognition is said to be 'the necessary primary concern', ${ }^{30}$ as the pre-condition for enforcement. Similarly, in cross-border bank resolution cases, upon the recognition of a foreign resolution action, some actions can take immediate effect in the domestic regime without additional enforcement, some can be

and Europe Volume 2: European Union Matthias Haentjens, Qingjiang Kong and Bob Wessels (eds) (Eleven International Publishing 2017) 192; Bob Wessels, 'International Insolvency Law and EU Bank Resolution Rules' in M Haentjens and B Wessels (eds), Research Handbook on Cross-border Bank Resolution (Edward Elgar 2019); Matthias Lehmann, 'Conflict-of-law Issues' in Matthias Haentjens and Bob Wessels (eds), Research Handbook on Cross-Border Bank Resolution (Edward Elgar 2019).

27 FSB KA 7.5.

28 FSB Principles, 5-6.

29 A V Dicey, Dicey, Morris and Collins on the Conflict of Laws (J H C Morris, Lawrence Collins and Adrian Briggs eds, 15th edn, Sweet \& Maxwell Thomson Reuters 2012) para 14-002.

30 Adrian Briggs, The Conflict of Laws (OUP 2013) 116. See also Clarke v Fennoscandia Ltd [2007] UKHL 56, para 21. 
enforced directly as foreign actions, while others need to be transformed into domestic actions (supportive measures) to be effective. ${ }^{31}$ Therefore, these two mechanisms are placed under the same term 'recognition'. Unless specified otherwise, the discussions in this book apply to both.

In addition, the FSB Principles propose to adopt 'contractual recognition' to fill the gap until statutory approaches have been fully implemented or to reinforce the legal certainty and predictability. ${ }^{32}$ This is the private law approach discussed above. Contractual measures function by way of adding contractual provisions to private financial contracts that recognise actions taken by foreign resolution authorities. ${ }^{33}$ These contractual approaches largely reduce the possibility of private parties challenging foreign resolution actions; however, they have no binding effect on authorities designated to decide the effectiveness of foreign resolution actions. ${ }^{34}$ As contractual approaches form an integral part of giving effect to foreign resolution actions, they are mentioned as a supplementary tool to the general framework of recognition of foreign resolution actions.

In a cross-border context, at least two types of jurisdictions are involved, namely, a home jurisdiction where a resolution action is initiated, and a host jurisdiction where the action is sought to be recognised. The meaning of home/host will be explained in the terminology section. It is clarified here that recognition is mostly perceived from the host jurisdictions' perspective. Therefore, the legal framework for recognition is designed for host jurisdictions and imposes rights and obligations on host authorities. However, it cannot be overlooked that recognition is an interaction between home and host jurisdictions, and in order to reach a decision about recognition or not, actions and legal status of home authorities are necessary to be taken into account. Also, it is acknowledged that, although the subject examined in this book has international factors, the legal framework for recognition of foreign resolution actions rests on domestic legal instruments that can be unilaterally invoked by national authorities. Nonetheless, international standards such as the FSB Key Attributes are also important guidance for the formulation of national laws, and these standards are also frequently referred to throughout the book. In turn, principles proposed in this book are not restricted to apply in the domestic law context alone, but could inspire international agreements in more detail.

See Chapter 6 at $\$ 6.4 .4 .2$.

FSB Principles, 6-7, 13-16.

Ibid.

${ }^{34}$ See Chapter 6 at $§ 6.2 .3 .2$. 


\subsection{THE EUROPEAN UNION, THE UNITED STATES AND MAINLAND CHINA: A COMPARATIVE OVERVIEW}

This book undertakes positive law analysis and intends to investigate the status quo of presently available legal instruments to recognise foreign resolution actions. Given the limited resources and capacity, this book chooses three representative jurisdictions to conduct a comparative analysis, that is, the European Union (EU), the United States (US) and mainland China. ${ }^{35}$ The selection of these jurisdictions was for the following reasons. First, the EU, the US and China have the most G-SIBs. ${ }^{36}$ As of November 2020, there are in total $30 \mathrm{G}-\mathrm{SIBs}$, and eight of them are in the EU Member States, ${ }^{37}$ eight in the US, ${ }^{38}$ and four in China. ${ }^{39}$ The EU, the US and China are three of the largest economies in the world, and a study of them can present vital guidance for other jurisdictions as well.

Second, as introduced in the following paragraphs and, more specifically, Chapters 3 to 5, each jurisdiction has a different approach to recognition of foreign resolution actions. The EU Member States, as assessed by the FSB, have a comprehensive set of resolution rules in place, in line with the FSB Key Attributes. ${ }^{40}$ This is the result of the implementation of the Bank Recovery

35 The discussion of 'China' in this chapter is limited to mainland China and excludes Hong Kong, Macau and Taiwan.

36 FSB, '2020 list of global systemically important banks (G-SIBs)' (11 November 2020).

37 Ibid., Deutsche Bank (Germany), BNP Paribas (France), Group BPCE (France), Group Crédit Agricole (France), ING Bank (the Netherlands), Santander (Spain), Société Générale (France), Unicredit Group (Italy). There are another three G-SIBs in the United Kingdom (UK): HSBC (the UK), Barclays (the UK), and Standard Chartered (the UK).

38 Ibid., JP Morgan Chase, Citi Group, Bank of America, Goldman Sachs, Wells Fargo, Bank of New York Mellon, Morgan Stanley, and State Street.

39 Ibid., Bank of China, Industrial and Commercial Bank of China Limited, Agricultural Bank of China, and China Construction Bank.

40 FSB (n 10) 19-20. See a general overview of literature, e.g., Martin Čihák and Erlend Nier, The Need for Special Resolution Regimes for Financial Institutions: The Case of the European Union (International Monetary Fund 2009); Charles Randell, 'European Banking Union and Bank Resolution' (2013) 7 Law and Financial Markets Review 30; Kenadjian, The Bank Recovery and Resolution Directive Europe's Solution for 'Too Big To Fail'; Jeffrey N Gordon and Wolf-Georg Ringe, 'Bank Resolution in the European Banking Union: A Transatlantic Perspective on What It Would Take' (2015) Columbia Law Review 1297; Michael Schillig, 'The EU Resolution Toolbox' in Matthias Haentjens and Bob Wessels (eds), Research Handbook on Crisis Management in the Banking Sector (Edward Elgar Publishing 2015); Binder and Singh (n 4); Haentjens, Janssen and Wessels (n 26). 
and Resolution Directive (BRRD) ${ }^{41}$ and the Single Resolution Mechanism Regulation (SRMR). ${ }^{42}$ The BRRD and SRMR empower EU resolution authorities to directly recognise third-country resolution actions. ${ }^{43}$ In other words, the EU adopts an administrative regime of recognition. Most interestingly, the new EU resolution framework provides a special mechanism for cross-border resolution among EU Member States, including the establishment of a Single Resolution Board (SRB), ${ }^{44}$ which can be an inspiration for establishing a global cross-border mechanism.

During most of the time when this book was being written, the UK was an EU Member State. Thus, the EU section in this book also examines English law. However, as of midnight CET on 31 January 2020, Brexit is official, and the UK is a 'third country' to the EU. After a transition period, the EU law may then no longer apply in the UK. However, discussions regarding third country relations might apply. The issues regarding Brexit are explained in Chapter 3 at $\$ 3.3 .1 .1 .3$.

The US, after the financial crisis of 2008, promulgated the Dodd-Frank Wall Street Reform and Consumer Protection Act (Dodd-Frank Act), ${ }^{45}$ which

41 Directive 2014/59/EU of the European Parliament and of the Council of 15 May 2014 establishing a framework for the recovery and resolution of credit institutions and investment firms and amending Council Directive 82/891/EEC, and Directives 2001/24/EC, 2002/47/EC, 2004/25/EC, 2005/56/EC, 2007/36/EC, 2011/35/ EU, 2012/30/EU and 2013/36/EU, and Regulations (EU) No 1093/2010 and (EU) No 648/2012, of the European Parliament and of the Council, OJ L 173/190. See also the amendment BRRD II: Directive (EU) 2019/879 of The European Parliament and of the Council of 20 May 2019 amending Directive 2014/59/EU as regards the loss-absorbing and recapitalisation capacity of credit institutions and investment firms and Directive 98/26/EC, OJ L 150/296.

42 Regulation (EU) No 806/2014 of the European Parliament and of the Council of 15 July 2014 establishing uniform rules and a uniform procedure for the resolution of credit institutions and certain investment firms in the framework of a Single Resolution Mechanism and a Single Resolution Fund and amending Regulation (EU) No 1093/2010. See also the amendment SRMR II: Regulation (EU) 2019/877 of the European Parliament and of the Council of 20 May 2019 amending Regulation (EU) No 806/2014 as regards the loss-absorbing and recapitalisation capacity of credit institutions and investment firms, OJ L 150/226.

43 Articles 94-95 BRRD; Article 33 SRMR.

44 See, e.g., Troiano, 'Cross-border Cooperation between Resolution Authorities in the BRRD'; Geroge S. Zavvos and Stella Kaltsouni, 'The Single Resolution Mechanism in the European Banking Union: Legal Foundations, Governance Structure and Financing' in Matthias Haentjens and Bob Wessels (eds), Research Handbook on Crisis Management in the Banking Sector (Edward Elgar 2015); Haentjens, Janssen and Wessles (n 26) 155-198; Binder (n 24); Wessels (n 26).

45 The Dodd-Frank Wall Street Reform and Consumer Protection Act, Pub. L. 111-203, 21 July 2010, 124 Stat. 1386. 
expands the power of resolution from depository institutions, as stipulated in the Federal Deposit Insurance Act (FDIA), ${ }^{46}$ to other regulated financial institutions. ${ }^{47}$ The US resolution regime is also in line with the FSB Key Attributes. ${ }^{48}$ However, neither the Dodd-Frank Act nor the previous FDIA have special rules for recognition of foreign resolution actions. Chapter 15 of the US Bankruptcy Code can apply, ${ }^{49}$ except in circumstances where foreign banks have branches or agencies present in the US. ${ }^{50}$ Chapter 15 adopts the United Nations Commission on International Trade Law (UNCITRAL) Model Law on Cross-border Insolvency (MLCBI), which prescribes a judicial recognition regime for foreign insolvency proceedings. ${ }^{51}$

China, although being a home jurisdiction to four G-SIBs, is lagging behind in adopting a comprehensive resolution regime. ${ }^{52}$ The resolution of failing financial institutions still relies on the general Chinese Enterprise Bankruptcy Law (EBL). ${ }^{53} \mathrm{~A}$ most recent regulation is the Interim Measures for Banking 873.

46 The Federal Deposit Insurance Act, Pub. L. 81-797, 21 September 1950, 64 Stat.

47 See a general overview of literature, e.g., Skeel (n 3); Douglas G Baird, 'Dodd-Frank for Bankruptcy Lawyers' (2011) 19 American Bankruptcy Institute Law Review 287; Paul L Lee, 'Bankruptcy Alternatives to Title II of the Dodd-Frank Act-Part I' (2015) 132 Banking Law Journal 437; Paul L Lee, 'Bankruptcy Alternatives to Title II of the Dodd-Frank Act-Part II' (2015) 132 Banking Law Journal 503; Donald Bernstein and Reena Agrawal Sahni, 'United States' in Matthias Haentjens and Bob Wessels (eds), Research Handbook on Crisis Management in the Banking Sector (Edward Elgar 2015).

48 FSB (n 10) 24-27.

49 The Bankruptcy Abuse Prevention and Consumer Protection Act of 2005, Pub. L. No. 109-8, 20 April 2005, 119 Stat. 23.

5011 US Code $\S 109(\mathrm{~b})(3)(\mathrm{B}) ; 11$ US Code $\S 1501(\mathrm{c})(1)$.

51 See a general overview of literature, e.g., Ronald J Silverman, 'Advances in Cross-border Insolvency Cooperation: the UNCITRAL Model Law on Cross-border Insolvency' (1999) 6 ILSA Journal of International \& Comparative Law 265; Bob Wessels, International Insolvency Law Part I: Global Perspectives on Cross-Border Insolvency Law (4 ${ }^{\text {th }}$ edn, Kluwer 2015); Look Chan Ho, Cross-border Insolvency: A Commentary on the UNCITRAL Model Law (Global Law and Business 2017); Neil Hannan, Cross-border Insolvency: The Enactment and Interpretation of the UNCITRAL Model Law (Springer 2017). See also on the US Chapter 15, e.g., Jay L Westbrook, 'Chapter 15 at Last' (2005) 79 American Bankruptcy Law Journal 713; Jay L Westbrook, 'An Empirical Study of the Implementation in the United States of the Model Law on Cross Border Insolvency' (2013) 87 American Bankruptcy Law Journal 247; Leif M Clark and Daniel M Glosbank, Ancillary and Other Cross-border Insolvency Cases under Chapter 15 of the Bankruptcy Code (LexisNexis Matthew Bender 2008).

52 FSB (n 10) 24-27.

53 The Enterprise Bankruptcy Law of the People's Republic of China (《中华人民 共和国企业破产法》) was first promulgated on 2 December 1986 and came into force 
and Insurance Institutions on Implementing Recovery and Resolution Plans (RRP Measures). ${ }^{54}$ But the Measures still do not include specific resolution rules. For cross-border bank resolution, therefore, Article 5 of the EBL applies, which rests on a judicial recognition regime led by courts. ${ }^{55}$ However, unlike the US model, the Chinese judicial recognition is similar to recognition of foreign judgments under general private international law, without adopting the MLCBI and special rules for insolvency proceedings. ${ }^{56}$ Each of these three jurisdictions adopts a different approach to recognising foreign resolution actions, thus presenting the basis for further comparison.

It is acknowledged that this book does not cover all the jurisdictions. Although this book intends to formulate internationally applicable standards, it cannot be denied that additional research is needed to adapt these standards into specific domestic regimes. For instance, the selected jurisdictions may be the largest economies, and smaller economies might have different considerations.

on 1 November 1988. It was later amended on 27 August 2006, and the revision came into force on 1 June 2007. See a general overview of literature, e.g., Qingjiang Kong and Yinhui Sun, 'China' in Matthias Haentjens and Bob Wessels (eds), Research Handbook on Crisis Management in the Banking Sector (Edward Elgar 2015); Qingjiang Kong, New Bank Insolvency Law for China and Europe Volume 1: China (M. Haentjens, Qingjiang Kong and B. Wessels eds, Eleven International Publishing 2017); Jieche Su, Supervisory Liability of the Regulator in Bank Insolvency Proceedings (China University of Political Science and Law Press 2016); Aijun Li, Study on Legal Issues of Cross-border Insolvency of Commercial Banks 商业银行跨境破产法律问题研究 (China University of Political Science and Law Press 2012).

54 See CBIRC, 'Interim Measures for Banking and Insurance Institution on Implementing Recovery and Resolution Plans' (《银行保险机构恢复和处置计划实 施暂行办法》), Yin Bao Jian Fa [2021] No.16 (9 June 2021) http://www.cbirc.gov.cn/ $\mathrm{cn} /$ view/pages/ItemDetail.html?docId=989402\&itemId=928\&generaltype $=0$ accessed 30 June 2021.

55 See, e.g., Li (n 53); Shuai Guo, 'Conceptualising Upcoming Chinese Bank Insolvency Law: Cross-border Issues’ (2019) 28 International Insolvency Review 44; Armstrong Chen, 'An Analysis of the Development of Cross-border Crisis Management in China's Bankruptcy Law and Regulations' in Matthias Haentjens and Bob Wessels (eds), Research Handbook on Cross-border Bank Resolution (Edward Elgar 2019).

${ }_{56}$ See, e.g., Qingxiu Bu, 'China's Enterprise Bankruptcy Law (EBL 2006): Cross-border Perspectives' (2009) 18 International Insolvency Review 187; Guangjian $\mathrm{Tu}$ and Xiaolin Li, 'The Chinese Approach Toward Cross-Border Bankruptcy Proceedings: One Progressive Step Ahead' (2015) 24 International Insolvency Review 57; Parry Rebecca and Gao Nan, 'The Future Direction of China's Cross-border Insolvency Laws, Related Issues and Potential Problems' (2018) 27 International Insolvency Review 5. 


\subsection{POLICY GOALS AND LEGAL DOCTRINES}

This book also conducts normative analysis that encompasses both an external framework (policy goals) and an internal framework (legal doctrines). ${ }^{57}$

Recognition of foreign resolution actions needs to balance two policy goals: making home resolution actions effective across borders and protecting host interests. The former policy goal is extensively explained in Chapter 6 at $\$ 6.2 .3 .1$, and four reasons are provided: first, modern banks operate globally and are interconnected, and economic analysis shows that international cooperation in the resolution of cross-border operating banks can maintain global financial stability and incur less cost compared to individual resolution within national borders; ${ }^{58}$ second, recognition of foreign resolution actions follows the universalism principle enshrined in the modern international insolvency law, which facilitates a global administration system; ${ }^{59}$ third, recognition of foreign administrative resolution actions is a way of showing comity, ${ }^{60}$ which is a cornerstone for recognition of foreign judgments and arises from mutual interest and utility; ${ }^{61}$ fourth, res judicata ${ }^{62}$ prevents creditors from

57 Sanne Taekema, 'Theoretical and Normative Frameworks for Legal Research: Putting Theory into Practice' (2018) Law and Method 1, 7-9.

58 See, e.g., Zdenek Kudrna, 'Cross-Border Resolution of Failed Banks in the European Union after the Crisis: Business as Usual' (2012) 50 Journal of Common Market Studies 283; Gleeson, 'The Importance of Group Resolution'; Thomas F Huertas, 'Safe to Fail' (2013) Special Paper 221 LSE Financial Markets Group Special Paper Series; Charles Randell, 'Group Resolution under the EU Resolution Directive' in Dombret and Kenadjian (n 24).

59 See, e.g., Jay L Westbrook, 'A Global Solution to Multinational Default' (2000) 98 Michigan Law Review 2276; Andrew T Guzman, 'International Bankruptcy: In Defense of Universalism' (2000) 98 Michigan Law Review 2177; Ian F Fletcher, Insolvency in Private International Law (OUP 2005); Wessels (n 51) para 10010; Reinhard Bork, Principles of Cross-border Insolvency Law (Intersentia 2017) 26-28; Irit Mevorach, The Future of Cross-Border Insolvency: Overcoming Biases and Closing Gaps (OUP 2018) 755-766.

${ }^{60}$ See, e.g., Ernest G Lorenzen, ‘Huber's De Conflictu Legum' (1919) 13 Illinois Law Review 53; Tim W Dornis, 'Chapter C. 18: Comity' in Jürgen Basedow and others (eds), Encyclopedia of Private International Law (Edward Elgar 2017).

${ }_{61}$ Joseph Story, Commentaries on the Conflict of Laws, Foreign and Domestic, in Regard to Contracts, Rights, and Remedies, and Especially in Regard to Marriages, Divorces, Wills, Successions, and Judgments (Hilliard, Gray, and Company 1834) §35.

62 See, e.g., Hans Smit, 'International Res Judicata and Collateral Estoppel in the United States' (1962) 9 UCLA L Rev 44; Courtland H Peterson, 'Res Judicata and Foreign Country Judgments' (1963) 24 Ohio St LJ 291; Peter Barnett, Res Judicata, Estoppel, and Foreign Judgments (OUP 2001). 
initiating a second proceeding, and the obligation doctrine ${ }^{63}$ confirms that the creditor-debtor relationship has been altered by the original resolution action.

On the other hand, Chapters 7 and 8 demonstrate that home jurisdictions usually do not have national or international legal obligations or internal incentives to fully consider the host jurisdictions' interests. Resolution authorities are administrative authorities, part of the executive branch/government, and are only accountable to domestic constituencies such as taxpayers, financial institutions and depositors, and therefore they only need to protect home interests. This reality explains the necessity for host authorities to take counter measures to prevent negative or adverse effects from home resolution actions, namely, refusal of recognition, with the aim of protecting host interests.

The two policy goals just discussed correspond to the two sides of a recognition mechanism: reasons for recognition and grounds for refusal of recognition. The FSB also clearly stated that both perspectives need to be taken into account. ${ }^{64}$ Setting the external framework and identifying the policy goals determine the major issues to be discussed in the context of a (possible) legal framework. Therefore, this book will formulate the general legal framework by taking into account these two opposite aspects.

The boundaries of the recognition framework are set by the external aspect of normative examination, yet specific rules within the recognition framework rely on the internal aspect. In this book, the internal framework draws inspiration from the legal doctrines in the fields of private international law, financial law and insolvency law. Examination of these legal doctrines assists in three ways. First, doctrines, such as comity or universalism, explain why a jurisdiction should recognise a foreign judgment or a foreign insolvency proceeding and, therefore, provide the theoretical rationale for the position that foreign resolution actions should be recognised or not. Second, doctrines, particularly those related to private international law and international insolvency law such as reciprocity, set out the conditions and procedures for recognition of foreign judgments and foreign insolvency proceedings and can help determine which issues should be considered when formulating the legal framework. Third, doctrines, such as (national/domestic) financial stability or equal treatment of creditors, serve as benchmarks to answer the questions raised in the second point.

The discussion of private international law seems obvious because private international law rests on three major pillars: jurisdiction, applicable law and

63 See, e.g., Dicey (n 29) para 14-007; Trevor C Hartley, International Commercial Litigation: Texts, Cases and Materials on Private International Law (2nd edn, CUP 2015) 350 .

${ }^{64}$ FSB Principles, 12. 
recognition and enforcement of foreign judgments, and recognition of foreign resolution actions closely relates to the third pillar. It is acknowledged that private international law usually deals with judicial judgments rather than administrative resolution actions. This book, however, argues that private international law doctrines serve at least two purposes. First, the rationale behind giving effect to foreign judgments can be extended to recognition of foreign resolution actions. For instance, the comity doctrine means that a jurisdiction shows courtesy to another jurisdiction; it applies to not only judicial actions but also administrative actions. Second, existing rules of private international law can be the inspiration for creating rules for recognition of foreign resolution actions, including the determination of jurisdiction (competent authority to take resolution actions), conditions and procedures for recognition (including reciprocity), effects of recognition (automatic effect and enforcement), as well as refusal of recognition (public policies). In particular, international insolvency law can also directly apply to resolution cases, for example in the US, considering that resolution is a special procedure of insolvency, while rules of international insolvency law largely derive from general principles of private international law. Therefore, based on the doctrines in the field of private international law, Chapter 6 studies the rules regarding determination of jurisdiction, conditions and procedures for recognition and effects of recognition, while Chapters 7 and 8 deal with public policies.

Financial law doctrines are also examined given the subject discussed in this book is banks. In particular, Chapter 7 focuses on financial stability, which is a general principle of financial law and a major objective of resolution. Maintaining global and international financial stability is a rationale for an effective cross-border bank resolution regime and is one of the reasons to recognise foreign resolution actions. However, it is acknowledged that financial regulators and supervisors are only accountable to their domestic constituencies, and home resolution authorities only need to consider home interests and thus may neglect interests of host jurisdictions. Therefore, a host jurisdiction may refuse to recognise foreign home resolution actions, with the purpose of protecting host interests, such as the host jurisdiction's financial stability or avoiding any adverse impact on the host jurisdiction's fiscal policy. Chapter 7 specifically examines these situations.

International insolvency law is another important perspective for the internal analysis. This book views resolution under the general framework of insolvency, ${ }^{65}$ and international insolvency law doctrines, especially the debates concerning territoriality and universality, help to interpret why foreign resolution actions should be recognised. Besides, international insolvency law relies

65 See discussions in Chapter 2, §2.1. 
on the same pillars as private international law, that is, jurisdiction, applicable law, and recognition and enforcement. Similarly, international insolvency law doctrines can also be the model for designing specific rules for the recognition of foreign bank resolution actions, including the determination of jurisdiction (centre of main interest (COMI)/establishment), conditions and procedures for recognition, effects of recognition, as well as refusal of recognition. The first three issues are examined in Chapter 6. A particular issue and major concern of international insolvency is the creditors' position which is examined in Chapter 8. Doctrines concerning creditors have two implications: on the one hand, creditors are supposed to be treated equally, and a host jurisdiction should recognise home proceedings, so that host creditors should also be placed under the same home proceedings; on the other hand, protection of host creditors' interests is a common reason for refusal of recognition. Creditors' positions are therefore examined from both sides in the process of recognising foreign resolution actions.

\subsection{TERMINOLOGY}

First, in this book, bank resolution refers to actions taken by administrative resolution authorities to resolve banks that are failing or likely to fail. Chapter 2 elaborates this concept and explains that resolution is under the general framework of insolvency/bankruptcy. Some insolvency-related rules are also applicable to resolution, subject to special characteristics of resolution. Any action falling outside the scope of resolution, for example, a court-led liquidation/winding-up proceeding, is not discussed in this book, nor are any resolution actions in relation to insurance companies, central counterparties (CCPs), or financial market infrastructures (FMIs).

It is also worth noting that the FSB distinguishes two different stages recovery and resolution. ${ }^{66}$ Recovery measures should be implemented before placing a bank into resolution, including measures to reduce the risk profile of a bank and conserve capital, as well as considering strategic options, such as divestiture of business lines and restructuring of liabilities. ${ }^{67}$ Unlike resolution, recovery usually only involves a change in a bank's business strategy and does not substantively alter the debtor-creditor relationship. This book focuses on resolution actions but not recovery.

Second, resolution action is used as an umbrella term in this book, encompassing both resolution proceedings and resolution measures. Resolution actions are a collection of actions, consisting of the commencement of resolu-

\footnotetext{
66 FSB KA 11.

67 FSB KA I-Annex 4, para 1.5.
} 
tion proceedings and the exercise of resolution measures. Resolution proceedings are ongoing processes, having continuous effects, following a decision to place a bank under resolution. Resolution measures take place after a bank has been put into resolution and have immediate effects. As explained in Chapter 6 , the two different terms enable us to distinguish between the different procedures and effects of proceedings and those of measures. Recognising foreign resolution proceedings has ongoing continuous effects; while recognising foreign resolution measures requires immediate effect. Unless specified otherwise, other discussions in this book apply to both resolution proceedings and resolution actions.

Third, in terms of cross-border cases, inevitably there are two or more jurisdictions, and this book adopts the distinction of home and host jurisdictions as made by the FSB. A home jurisdiction refers to a jurisdiction where 'the operations of a bank or financial group are supervised on a consolidated basis', ${ }^{68}$ which, normally, is where the parent or holding company is located. A host jurisdiction refers to a jurisdiction where subsidiaries, branches, and assets are located, or the law of which is chosen as the governing law. ${ }^{69}$ The terms, nevertheless, are different from the concepts in the EU law. According to the Capital Requirements Regulation ${ }^{70}$ (CRR), a home Member State means 'the Member State in which an institution has been granted authorisation', and a host Member State means 'the Member State in which an institution has a branch or in which it provides services'. ${ }^{71}$ Simply put, an EU Member State where a subsidiary of a non-EU third-country bank is located is a host jurisdiction in this book but a home jurisdiction in the EU context. $§ 6.4 .2$ in Chapter 6 provides a more detailed explanation.

\subsection{OUTLINE}

In the remainder of Part I Introductory Chapters, Chapter 2 explains the concepts of bank resolution and sets out different scenarios of cross-border bank resolution.

${ }^{68}$ FSB, 'Key Attributes Assessment Methodology for the Banking Sector: Methodology for Assessing the Implementation of the Key Attributes of Effective Resolution Regimes for Financial Institutions in the Banking Sector' (19 October 2016) (KAAM).

69 See FSB Principles, 5.

70 Regulation (EU) No 575/2013 of the European Parliament and of the Council of 26 June 2013 on prudential requirements for credit institutions and investment firms and amending Regulation (EU) No 648/2012, OJ L 176/1.

${ }^{71}$ Art 4(1)(43) and (44) CRR. 
Part II is the main part of the comparative law analysis. Legal systems in the EU (Chapter 3), the US (Chapter 4) and China (Chapter 5) are illustrated respectively. Discussions about each jurisdiction include regulation, supervision and resolution frameworks, as well as rules for recognition of foreign resolution actions.

Part III conducts the comparison and evaluation of three normative benchmarks, namely, grounds for recognition (Chapter 6), financial stability and resolution objectives (Chapter 7) and the creditors' position (Chapter 8). Each chapter starts with a theoretical framework, followed by a comparison and evaluation of specific national laws.

Part IV is the concluding part of the book. Chapter 9 proposes a future framework for cross-border recognition of foreign resolution actions, including domestic law instruments, international agreements, a model Law, customary international law and soft law. Chapter 10 is the conclusion.

This book takes into account development up to 30 June 2021. 